\title{
Fixed point results of cyclic contractions in product spaces
}

\section{SATISH SHUKLA and MUJAHID ABBAS}

\section{ABSTRACT.}

In this paper, the well known concept of cyclic contraction is generalized in product spaces by introducing a new class of operators called cyclic-Prešić operators. A fixed point result for such operators is proved. Some examples are given to validate the results proved herein.

Acknowledgement. Authors are thankful to the referees for their valuable suggestions on this paper. First author is thankful to Professor Stojan Radenović for his suggestions and the motivation for this work.

\section{REFERENCES}

[1] Chen, Y. Z., A Prešić type contractive condition and its applications, Nonlinear Anal., (2009), doi:10.1016/j.na.2009.03.006

[2] Ćirić, L. B. and Prešić, S. B., On Preši ć type generalisation of Banach contraction principle, Acta. Math. Univ. Com., LXXVI (2007), No. 2, 143-147

[3] George, R., Reshma, K. P. and Rajagopalan, R., A generalised fixed point theorem of Prešić type in cone metric spaces and application to Morkov process, Fixed Point Theory Appl., (2011), doi:10.1186/1687-1812-2011-85

[4] Khan, M. S., Berzig, M. and Samet, B., Some convergence results for iterative sequences of Prešić type and applications, Advances in Difference Equations, (2012), doi:10.1186/1687-1847-2012-38

[5] Kirk, W. A., Srinivasan, P. S. and Veeramani, P., Fixed points for mappings satisfying cyclical contractive conditions, Fixed Point Theory 4 (2003), No. 1, 79-89

[6] Malhotra, S. K., Shukla, S. and Sen, R., A generalization of Banach contraction principle in ordered cone metric spaces, J. Adv. Math. Stud., 5 (2012), No. 2, 59-67

[7] Nashine, H. K., Kadelburg, Z. and Radenović, S., Fixed point theorems via various cyclic contractive conditions in partial metric spaces, Publications De L'Institut Mathématique, Nouvelle série, tome, 93 (107) (2013), 69-93

[8] Păcurar, M., A multi-step iterative method for approximating common fixed points of Prešić-Rus type operators on metric spaces, Studia Univ. "Babeş-Bolyai", Mathematica, LV, No. 1, March 2010

[9] Pǎcurar, M., Approximating common fixed points of Prešić-Kannan type operators by a multi-step iterative method, An. Şt. Univ. Ovidius Constanţa, 17 (2009), No. 1., 153-168

[10] Păcurar, M., Common fixed points for almost Prešić type operators, Carpathian J. Math., 28 (2012), No. 1., 117-126

[11] Prešić, S. B., Sur la convergence des suites, Comptes Rendus de l'Acad. des Sci. de Paris, 260 (1965), 3828-3830

[12] Prešić, S. B., Sur une classe d'inéquations aux diffćerences finite et sur la convergence de certaines suites, Publ. de L'Inst. Math. Belgrade, 5(19) (1965), 75-78

[13] Rao, K. P. R., Mustaq Ali, Md. and Fisher, B., Some Presic Type Generalizations of the Banach Contraction Principle, Mathematica Moravica, 15 (2011), No. 1, 41-47

[14] Shukla, S., Prešić type results in 2-Banach spaces, Afr. Mat., (2013), DOI 10.1007/s13370-013-0174-2

[15] Shukla, S., Set-valued Prešić-Ćirić type contraction in 0-complete partial metric spaces, Matematički vesnik, 66 (2014), No. 2, 178-189

[16] Shukla, S. and Fisher, B., A generalization of Prešić type mappings in metric-like spaces, Journal of Operators, 2013, Article ID 368501, 5 pages. http:/ / dx.doi.org/10.1155/2013/368501

[17] Shukla, S., Sen, R. and Radenović, S., Set-valued Prešić type contraction in metric spaces, An. Ştiinţ. Univ. Al. I. Cuza Iaşi. Mat. (N.S.), (Accepted) (2012)

Received: 18.07.2013; In revised form: 08.01.2014; Accepted: 23.04.2014

2010 Mathematics Subject Classification. 54H25, 47H10.

Key words and phrases. Cyclic contraction, Prešić type mapping, fixed point.

Corresponding author: Satish Shukla; satishmathematics@yahoo.co.in 
[18] Shukla, S. and Sen, R., Set-valued Prešić-Reich type mappings in metric spaces, Revista de la Real Academia de Ciencias Exactas, Fisicas y Naturales. Serie A. Matematicas, DOI 10.1007/s13398-012-0114-2

[19] Shukla, S., Radenović, S. and Pantelić S., Some fixed point theorems for Prešić-Hardy-Rogers type contractions in metric spaces, Journal of Mathematics, 2013, Article ID 295093, 8 pages http:/ /dx.doi.org/10.1155/2013/295093

[20] Shukla, S., Radojević, S., Veljković, Z. A. and Radenović, S., Some coincidence and common fixed point theorems for ordered Prešić-Reich type contractions, Journal of Inequalities and Applications, 2013, 2013:520 DOI 10.1186/1029-242X-2013-520

\section{Department of Applied Mathematics}

SHRI VAISHNAV INSTITUTE OF TECHNOLOGY \& SCIENCE

GRAM BAROLI, SANWER ROAD, INDORE (M.P.) 453331, INDIA

E-mail address: satishmathematics@yahoo.co.in

Department of MAthematics AND Applied Mathematics

UNIVERSITY OF PRETORIA

LYNNWOOD ROAD, PRETORIA 0002, SOUTH AFRICA

E-mail address: mujahidabbas14@yahoo.com 